should submit accounts of their work by October 31 . The work dealt with must have been carried out by the candidate in the United Kingdom mainly during the past five years. Further particulars may be obtained from the Secretary, Royal Horticultural Society, Vincent Square, Westminster, S.W.1.

\section{Rockefeller Medical Fellowships}

THE Medical Research Council announces that the following awards of travelling fellowships for the academic year 1935-36 have been made on behalf of the Rockefeller Foundation of New York : Dr. D. F. Anderson, professor of midwifery and gynæcology, Anderson College of Medicine, Glasgow; Mr. N. R. Barrett, demonstrator of anatomy and chief assistant to the Surgical Unit, St. Thomas's Hospital, London ; Mr. A. C. P. Campbell, clinical tutor in medicine, Royal Infirmary, Edinburgh, and assistant lecturer, Department of Pathology, University of Edinburgh ; Mr. D. H. K. Lee, Sharpey Scholar, Department of Physiology, University College, London; Mr. J. E. A. O'Connell, demonstrator in anatomy, St. Bartholomew's Hospital Medical School, London; Mr. R. Walmsley, assistant in anatomy, University of Edinburgh. All the fellowships awarded this year are tenable in the United States.

\section{International Medical Post-Graduate Congress}

THE seventh International Medical Post-Graduate Congress of the Tomarkin Foundation, New York, which has been organised under the auspices of the Université Libre de Bruxelles, will be held at Brussels on September 12-19 and at Spa on September 20October 2. The proceedings at Brussels will include an international commemoration of Pierre Curie and Mme. Curie by a discussion on cancer, in which the Tomarkin Foundation will be assisted by the International Union against Cancer, and communications on tropical, subtropical and infectious diseases, and neurology; while the Spa meeting will be devoted to diseases of the cardio-vascular system and diseases of the blood. Papers on miscellaneous topics will be read at both meetings. The subscription terms are as follows : Full Congress, 80 belgas; half Congress, (Brussels or Spa), 50 belgas; single section, 30 belgas. On termination of the Congress, a visit will be paid to the principal Italian universities (Milan, Pavia, Bologna, Florence and Rome) and the most important sanitary institutes. The tour will last 10-12 days and the inclusive fare will be about 1,500 lire. Further information can be obtained from the Secretary, Tomarkin Foundation, 97 rue aux Laines, Bruxelles.

\section{Announcements}

Prof. Jean Lepine, Dean of the Lyons Faculty of Medicine, has been elected a member of the French Academy of Moral and Political Sciences.

THE Secretary of State for the Colonies has made the following appointments: Mr. J. M. Taylor, to be chief fruit inspector, Palestine; Mr. A. H. Weir, senior assistant conservator of forests, to be assistant deputy conservator of forests, Nigeria; Mr. A. E. Colman-Doscas, agricultural field officer, Federated Malay States, to be State agricultural officer, Johore; Mr. J. C. Nauen, horticulturist, Bermuda, to be assistant curator, Gardens Departments, Straits Settlements; Mr. R. O. Williams, assistant director of agriculture, Trinidad, to be chief horticultural officer, Palestine.

There are at present fourteen different localities in the Soviet Union for squadrons of sanitary aviation and their number will be considerably increased in the course of the year. The Moscow squadron which was established in the spring of 1934 has already flown 534 hours and covered 67,680 kilometres in transporting 28 sick or wounded persons, 34 doctors, 48 litres of blood for transfusion and $500 \mathrm{kgm}$. of medical apparatus.

Applications are invited for the following appointments, on or before the dates mentioned:

A probationary assistant lecturer in mathematics in University College, Bangor-The Registrar (July 15).

A lecturer in mechanical and civil engineering in the Technical College, Sunderland-The Chief Education Officer, Education Offices, 15, John Street, Sunderland (July 16).

A resident tutor (male) in geography at the Borough Road College, Isleworth-Principal (July 17).

A junior forestry inspector in the Department of Lands, Irish Free State-Secretary, Civil Service Commission, 45 Upper O'Connell Street, Dublin, C.8 (July 18).

A teacher with qualifications in zoology, botany and chemistry in the Northampton College of Technology-Secretary, Education Office, Northampton (July 18).

An assistant teacher of mining subjects in the Doncaster Technical College-Secretary, Education Offices, Doncaster (July 19).

A woman lecturer in mathematics and biology or geography in the Swansea Training College for Women-The Director of Education, The Guildhall, Swansea (July 19).

An assistant to the secretaries of the Institution of Professional Civil Servants-Honorary Secretary (July 20).

Assistant civil engineers in the Civil Engineer-inChief's Department, Admiralty and H.M. Naval Establishment-The Civil Engineer-in-Chief, Admiralty, London, S.W.1 (July 31).

An assistant lecturer in physiology in University College, Cardiff-The Registrar (Aug. 31).

An assistant in the Department of Mechanical Engineering, Guildford Technical College-The Director.

An assistant lecturer in civil engineering in the Battersea Polytechnic, London, S.W.11-The Principal.

An inspector of machinery in the Mines Department of the Gold Coast Government-Crown Agents for the Colonies, 4 Millbank, S.W.1, quoting M/3793. 